\title{
Active defense against Varroa mites in a Carniolan strain of honeybee (Apis mellifera carnica Pollmann)
}

\author{
F Ruttner 1, H Hänel 2 \\ 1 Universität Frankfurt, Institut für Bienenkunde (Polytechnische Gesellschaft), \\ Fachbereich Biologie, Karl von Frisch-Weg 2, D-W-370 Oberursel; \\ 2 Hoechst AG, PO Box 800320, D-W-6330 FrankfurtM, Germany
}

(Received 1 December 1992; accepted 25 February 1992)

\begin{abstract}
Summary - Out of 700 hives ( $A$ m carnica) owned by a commercial beekeeper 12 colonies were selected which showed slower Varroa population growth, high mite mortality and good overwintering without treatment. Thirty to 50 percent of the dead mites had damaged legs and (rarely) cuticle of the idiosoma. The damage rate increased significantly with mite mortality level. By investigating freshly killed mites it was concluded that the damage was caused by the mandibles of worker bees. SEM photos of the mandibles indicate that they act like sharp scissors and that no substantial differences exist between $A$ mellifera and $A$ cerana.
\end{abstract}

Apis mellifera carnica / Varroa resistance / amputation / mandible / defensive behavior

\section{INTRODUCTION}

The Asiatic honeybee Apis cerana $\mathrm{F}$ has a number of defense mechanisms to keep the population of the ectoparasitic mite Varroa jacobsoni Oud within restricted limits and to ward off damage. One of these mechanisms as described by Peng et al (1987), is the active removal of adult mites from the bodies of worker bees and brood cells. This process involves selfcleaning behavior after showing signs of irritation, grooming dance, nestmate cleaning and group cleaning behavior. Each of the different types of cleaning behavior frequently resulted in the removal and eventual killing of the mite. $73.8 \%$ of the mites that dropped onto the hive bottom showed injuries to the body.
While experimentally introduced mites were removed from $A$ cerana in a very high percentage, colonies of European origin ( $A$ mellifera of unspecified subspecies) showed only vestiges of this behavior due to their "limited capability to recognize the mite as a pest" (Peng et al, 1987), and to their mandibles supposedly not suited to bite as strongly as those of the Asian honeybee. The removal rate of $A$ mellifera was observed to be $0.3 \%$ (Peng et al, 1987). In Brazil, however, Moretto et al (1991) found a very similar behavior in Africanized hybrids of $A$ mellifera with an average removal rate of $38.5 \%$ (range $10-70 \%$ ). Killed or mutilated mites were found only rarely. The same effect, but to a much reduced degree, was found with simultaneously tested colonies of $A$ m ligustica with a mean removal rate of $5.75 \%$. 
The high variance of this behavior found in these experiments and the experience that other $A$ cerana resistance mechanisms such as infertility of the Varroa in worker brood also exist in European races of $A$ mellifera (Ruttner et al, 1984) prompted a search in other Apis mellifera subspecies for a higher removal incidence, as already suggested by Peng et al (1987). Proving that $A m$ carnica has the behavioral, anatomical and physiological capacity of removing and killing living Varroa mites from the colony was the aim of this investigation.

\section{MATERIALS AND METHODS}

During the summer of 1990 , Alois Wallner, a commercial beekeeper in Austria, selected a dozen colonies from his apiary of 700 colonies which showed a distinctly slower development of the Varroa population during the season (Wallner, 1990). Whether the queens were related to each other is unknown. They were mated in the open. The selection process, ingeniously simple for a field test, was performed by the beekeeper during the summer of 1990: first, in spring and early summer, checks of the speed of the mite population increase in all colonies were made by simply breaking open sealed drone brood, in order to count infested cells. The majority of colonies was thereby excluded from the experiment. In the remaining colonies 20-50 capped worker brood cells were investigated bi-weekly for the presence of Varroa mites in late summer. Finally, less than $2 \%$ of all the colonies remained for further observation.

In contrast to the remainder (which was treated with formic acid) the selected colonies overwintered excellently without any chemotherapy. Further, the beekeeper noticed a high mite mortality and mutilation in a varying percentage of the mites. From September 1, 1990, to April 30, 1991, all the dead mites were collected daily from the bottom board (covered with a sheet of white paper and protected by a nylon net) except for 2 periods with very low temperatures when the mites were collected weekly. From 5 randomly chosen colonies of this group all dead mites $(n=6189$ ) were carefully examined under a stereomicroscope for injuries and abnormalities. The data were processed by an analysis of variance, using the SPSS PC package.

Some of the collected and mutilated mites were examined by using a scanning EM (Leitz $1600 \mathrm{~T}, 20 \mathrm{KV}$ ). To obtain freshly amputated mites, infested, freshly capped brood cells (containing prepupae or young pupae) of an "efficient mite remover colony" were opened and about a dozen mites set free; then the colony was closed again. After $10 \mathrm{~min}$, about 5-10 mites were found on the bottom board, some of which were still showing movements in spite of fresh amputation of one or several legs. These amputated mites were easily identified as originating from a capped brood cell by their swollen idiosoma (in contrast to the flat abdomen of a phoretic female). This method has the advantage of using mites from the same colony and thereby excluding reactions caused by foreign odors.

To obtain SEM pictures of mites with soft tissue, individuals still showing signs of life were fixed in $70 \%$ ethanol where they remained for up to 4 weeks. Afterwards the specimens were transferred for $12 \mathrm{~h}$ into $30 \%$ amyl acetate in ethanol. Passing through $70 \%$ amyl acetate in ethanol for $12 \mathrm{~h}$, they were then dehydrated in pure amyl acetate for $12 \mathrm{~h}$ with 3 changes. The mite specimens impregnated with amyl acetate were rinsed with liquid $\mathrm{CO}_{2}$ ( 3 changes every 2 h) within a critical-point-dryer (Polaron, Waterford, UK) and then carefully approached close to the critical point by slowly rising temperature. After reaching the critical point (disappearance of the liquid phase) the chamber was slowly brought down to normal pressure level. The dried specimens were glued to sample plates by means of Leit $C^{\circledR}$ (Leitz, Wetzlar, Germany) and investigated using the same SEM procedure as with other dry material.

\section{RESULTS}

\section{Mutilated mites}

\section{Kind of damage}

The mutilation of the mites varied from loss of a single apical segment to the complete 
loss of all 8 legs with the gnathosoma (figs 1, 2). Damage to the 2 front legs was the most frequent observation. Otherwise all thinkable combinations of damaged legs occurred, for instance unilateral loss of several legs or asymmetrical loss of single legs on both sides, and no pattern seemed to exist. Damage to the cuticle of the idiosoma was relatively rare $(1-2 \%)$. The stumps of mutilated legs had the appearance of an empty tube (even when the specimens had been collected at daily intervals), the chitin of the walls looked brittle, as if it was broken.

\section{Seasonal and individual frequency}

The total number of dead mites and mutilated individuals per month from September to April is given in table I. There seems to be a strong seasonal influence, although this was not statistically significant $(F 2.40$, prob $>F 0.0478$ ) probably due to the small number of colonies. The same was true for the differences between colonies ( $F$ 2.68, prob $>F 0.0527)$. There was, however, a highly significant correlation between the number of dead mites and the number of mutilated mites ( $F$ 133.40, prob $>F$ 0.0001).

As the colonies were part of the private selection program of the commercial beekeeper and were supposed to remain untreated and unmanipulated, there was no possibility of assessing their total infestation rate. Excellent control data from the same race of bees and from similar climatic conditions in the same province of Austria and from the same year were published by Moosbeckhofer (1991). In a group of 25 experimental unselected colonies, he observed an average of 72.8 dead

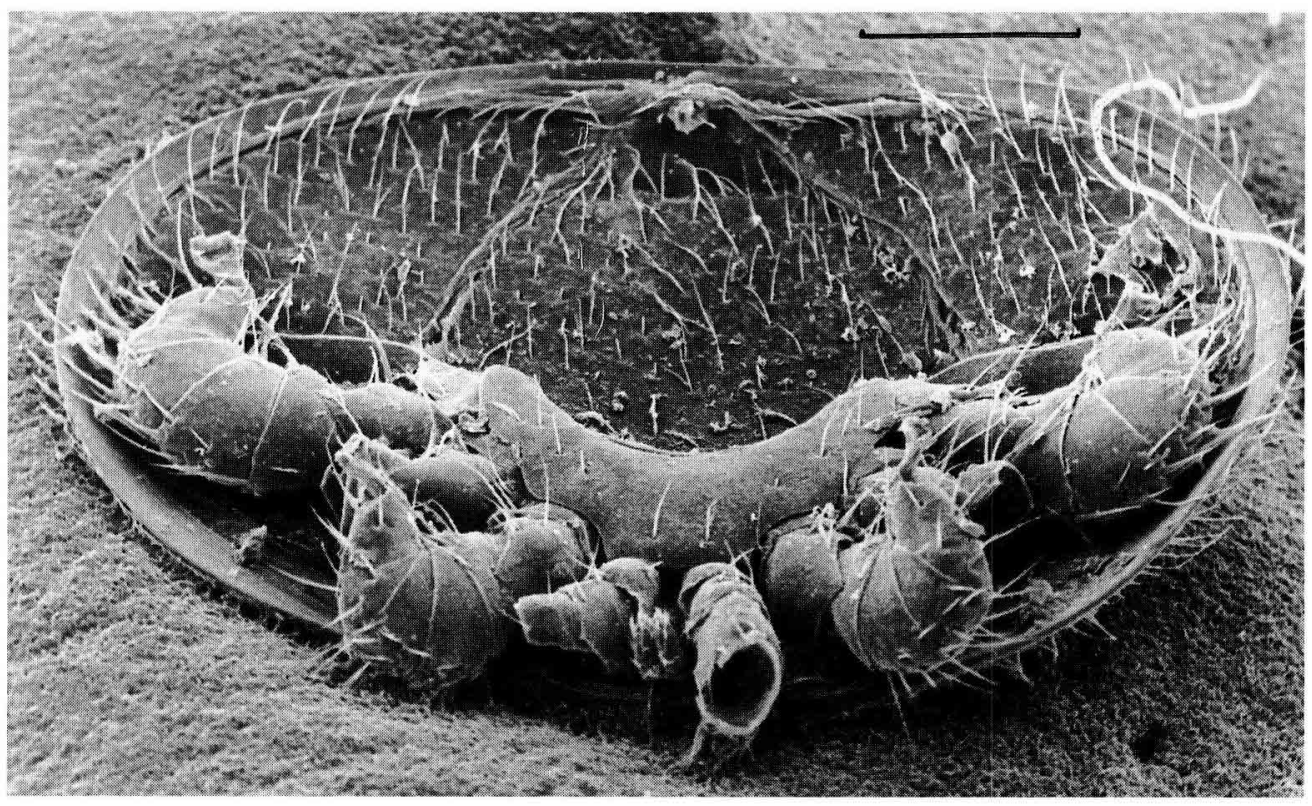

Fig 1. Dead Varroa mite collected from the bottom board of a selected $A m$ carnica colony. Legs 1 and 3 of both sides are damaged. Horizontal bar (hb): $0.2 \mathrm{~mm}$ (from Ruttner, 1991). 


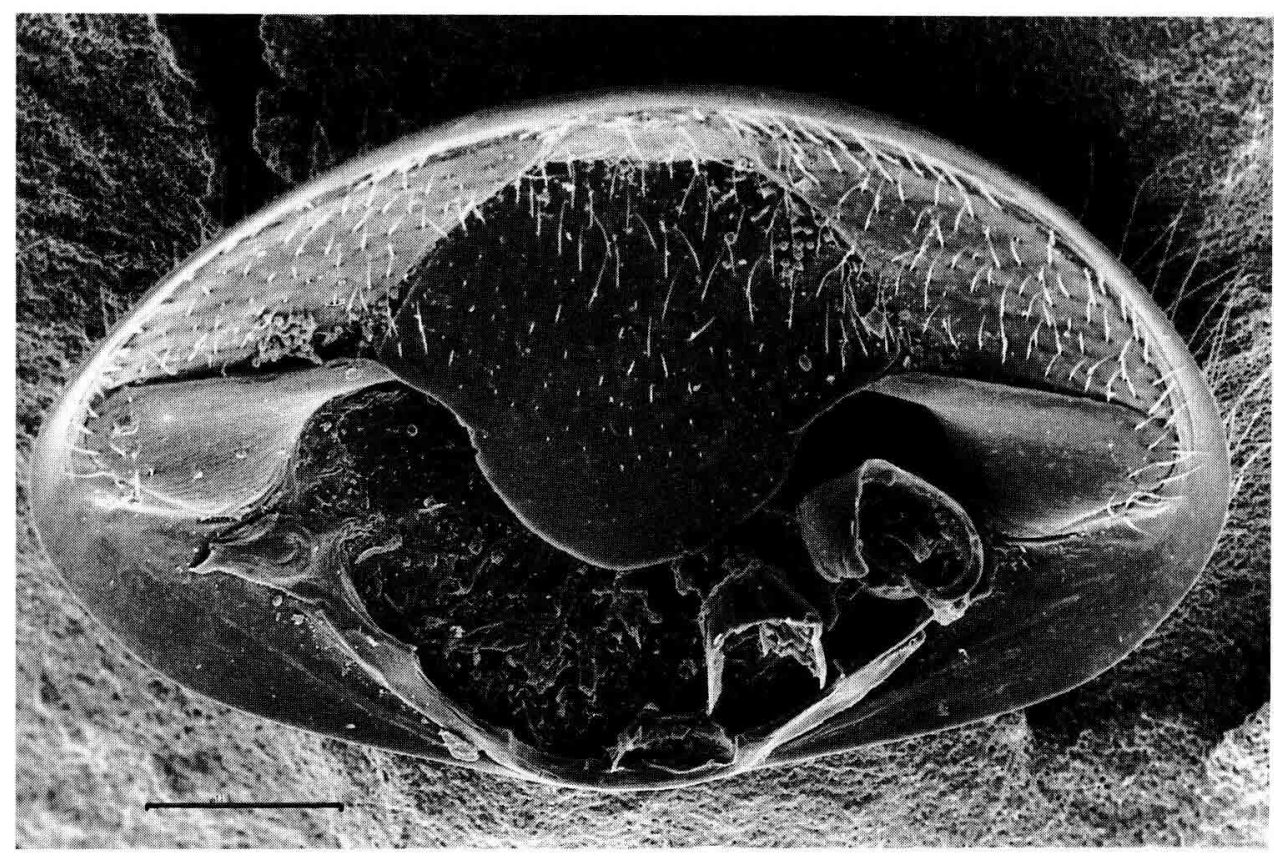

Fig 2. Mite without legs and gnathosoma collected from the same colony. hb: $0.2 \mathrm{~mm}$ (from Ruttner, 1991).

mites during the period Nov 8, 1990March 13, 1991. The mean number of mites per colony, assessed by Apistan ${ }^{\circledR}$ treatment in March-April 1991, was 459.8. From this an average Varroa winter mortality of $13.6 \%$ was calculated. The mean number of dead mites found in our 5 selected colonies for a comparable period (Nov 1-March 15, 1991) was 455.4 (range 257-726), ie 6-fold the amount of that observed in the aforementioned publication. According to Moosbeckhofer's figures this would correspond to $13.6 \%$ of the mites present in the colonies, which would imply a mean spring infestation of $\mathbf{3} \mathbf{3 5 0}$ mites, which is incompatible with survival of the colony. Hence a much higher mite mortality has to be concluded for our experimental colonies. Further experiments with se- lected colonies are needed to confirm this assumption.

\section{Cleaning and defense behavior}

So far, no extensive behavioral observations have been made on the selected colonies. However, short-term observations on a colony in a glass-walled observation hive or while managing a colony after release of mites revealed the same behavioral pattern as that described by Peng et al (1987) and Moretto et al (1991), including general unrest, cleaning movements and grooming dance of infested bees and nestmate cleaning. No clear direct observation of the removal of a mite from the body of a 


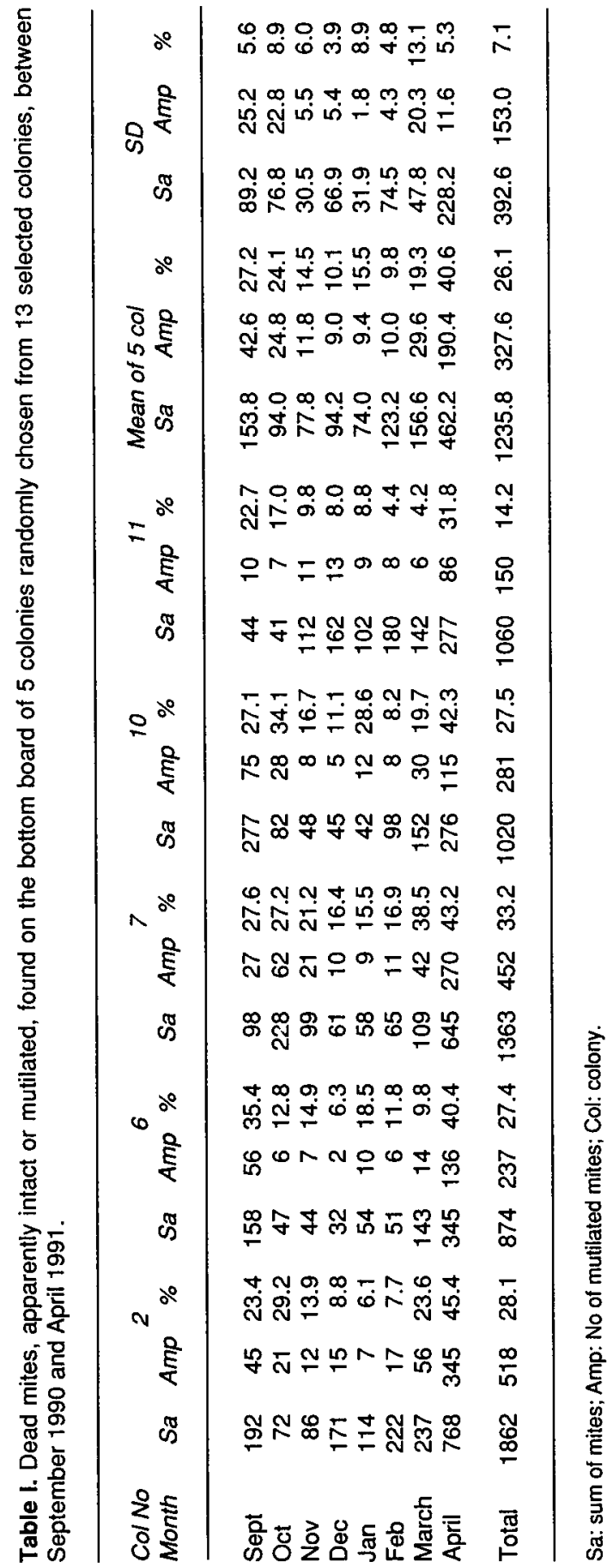


bee by self-cleaning or nestmate cleaning has been observed.

\section{Freshly amputated mites}

From the condition of the mutilated mites the cause of the damage cannot be inferred with certainty. Some believe that living mites were killed by the bees; others regard this as impossible with $A$ mellifera and hold ants or other arthropods responsible, or contend that these are old dry and brittle specimens which broke apart. Since direct observations are not yet available (given the relative scarcity of this event over a restricted period of time) we decided to resort to investigating freshly amputated and still living mites. It was not difficult to obtain specimens of this kind. Shortly after releasing a number of female Varroa from freshly sealed brood cells the typical unrest and cleaning behavior was observed on the respective comb. A few minutes later some amputated mites with legs still moving were collected from the bottom board.

The inspection of the amputated mites was a complete surprise. Instead of finding signs of gnawing, chewing or tearing apart, the muscular proximal joints of the legs showed a clear cut, even surface, of the chitinuous wall as well as of the muscles - as if severed by a sharp knife or a pair of scissors (figs 3-5). Sometimes a thin slice of muscle tissue was cut off, but still remaining in place (fig 3 ). In figure 4 , leg 2 was cut off on 2 different planes, leg 3 was cut by two-thirds; the rest was broken. In figure 5, the whole front part was removed, approaching the stage shown in figure 2. Only if the leg was damaged at one of the end joints, with remaining slender muscles, was the surface of the injury rugged and uneven (fig 6). Seeing these effects of the action of honeybee mandi-

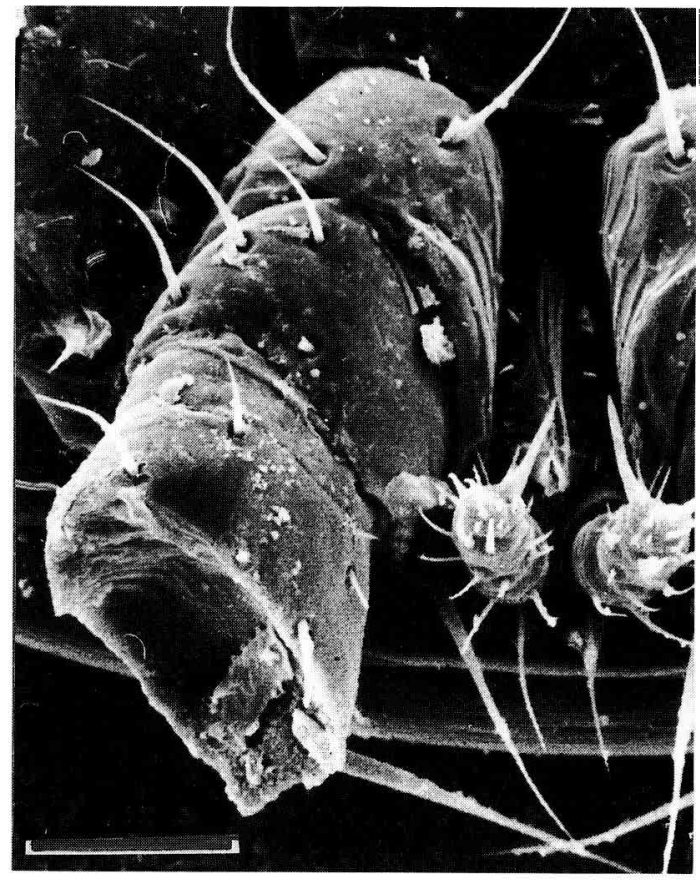

Fig 3. Freshly killed Varroa mite with leg 1 (left) amputated, collected from a selected $A m$ carnica colony. A slice of muscle tissue visible remaining on the cutting surface. hb: $0.05 \mathrm{~mm}$.

bles, a closer study of the mechanics of the biting organs seemed desirable.

\section{The cutting instruments: comparative anatomy of the mandibles and their muscles}

We compared bees of the Varroa tolerant strain belonging to the alpine population of A $m$ carnica with bees of $A$ cerana cerana from northern China. Although belonging to one of the largest subspecies, $A$ c cerana is distinctly smaller than $A m$ carnica (table II). 


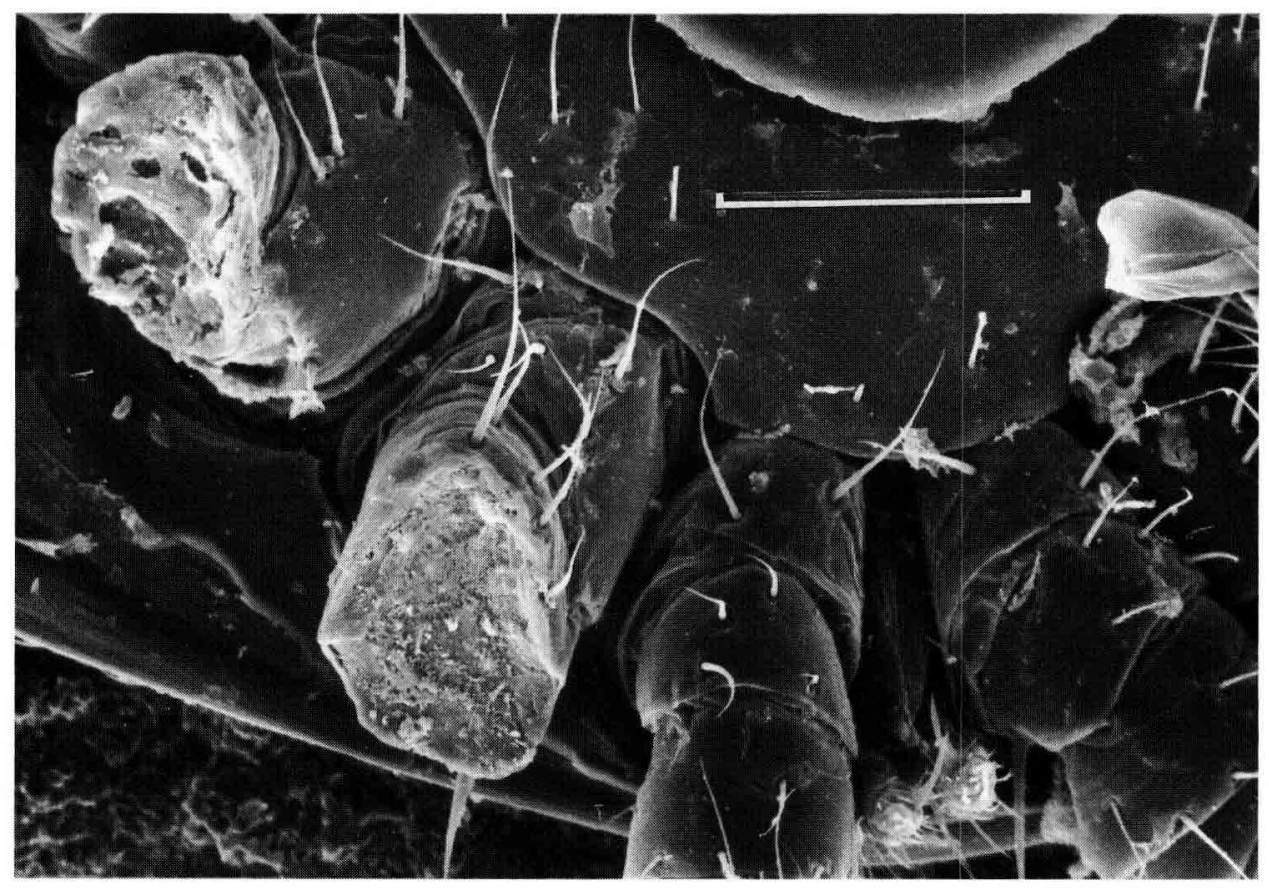

Fig 4. Similar to figure 3. Legs 2 and 3 (left) were amputated. Cutting plane not straight, but angled. hb: $0.1 \mathrm{~mm}$.

The head capsule of $A C$ cerana was slightly smaller in both dimensions than that of $A$ m carnica (fig 7 ). The mandibles were distinctly longer in $A m$ carnica than in A c cerana (table II, fig 8), but with shovels of about equal width. The 2 major muscles which move the mandibles were shorter in $A$ c cerana. but probably with more fibrils; only the long slender medial muscle was clearly larger in $A m$ carnica (fig 7).

The working rim of the mandible was a straight sharp edge in both species, with a mean length of $0.51 \mathrm{~mm}$ for $A C$ cerana and $0.59 \mathrm{~mm}$ for $A \mathrm{~m}$ carnica (5 worker mandibles were measured in each spe- cies). At higher magnification (figs 9,10 ) the edge compared well with that of a sharp knife. In figure 8 the diameter of a Varroa hind leg (basal joint) is shown in order to demonstrate that this is a powerful tool in both species to work a Varroa size body. A characteristic specific to the carnica mandible was a double edge in the basal half of the rim (figs 8,9 ). Small slices of tissue adhering to the surface of the cut muscle (fig 3 ) were probably due to the effect of this double edge. A sparse row of bristles was positioned at the inner side of the edge (fig 9), whereas the outer surface was completely bare at a narrow terminal stripe, with rectangularly bent bristles projecting downward over it (fig 10). 


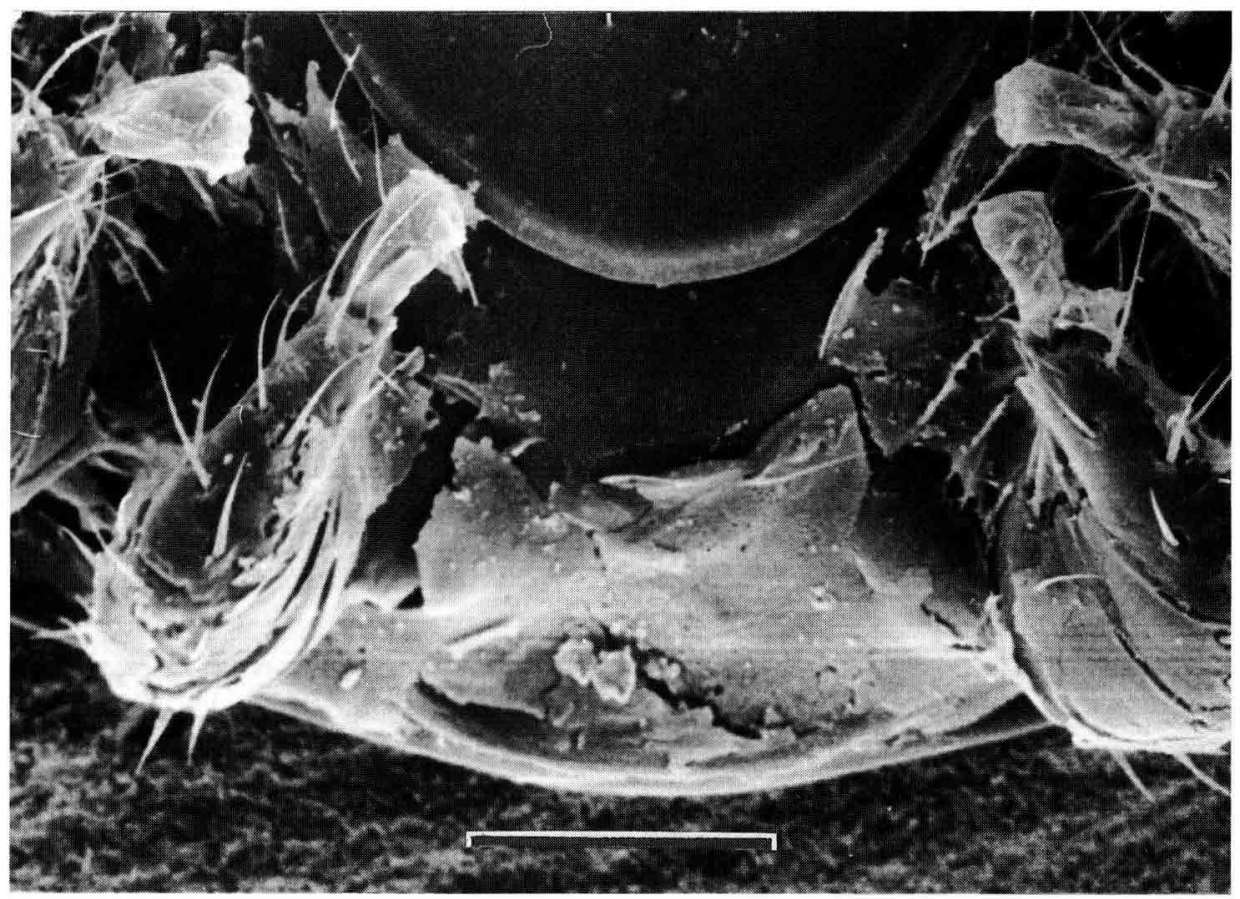

Fig 5. Both front legs and gnathosoma removed at the base - initial stage of that shown in figure 2 . hb: $0.1 \mathrm{~mm}$.

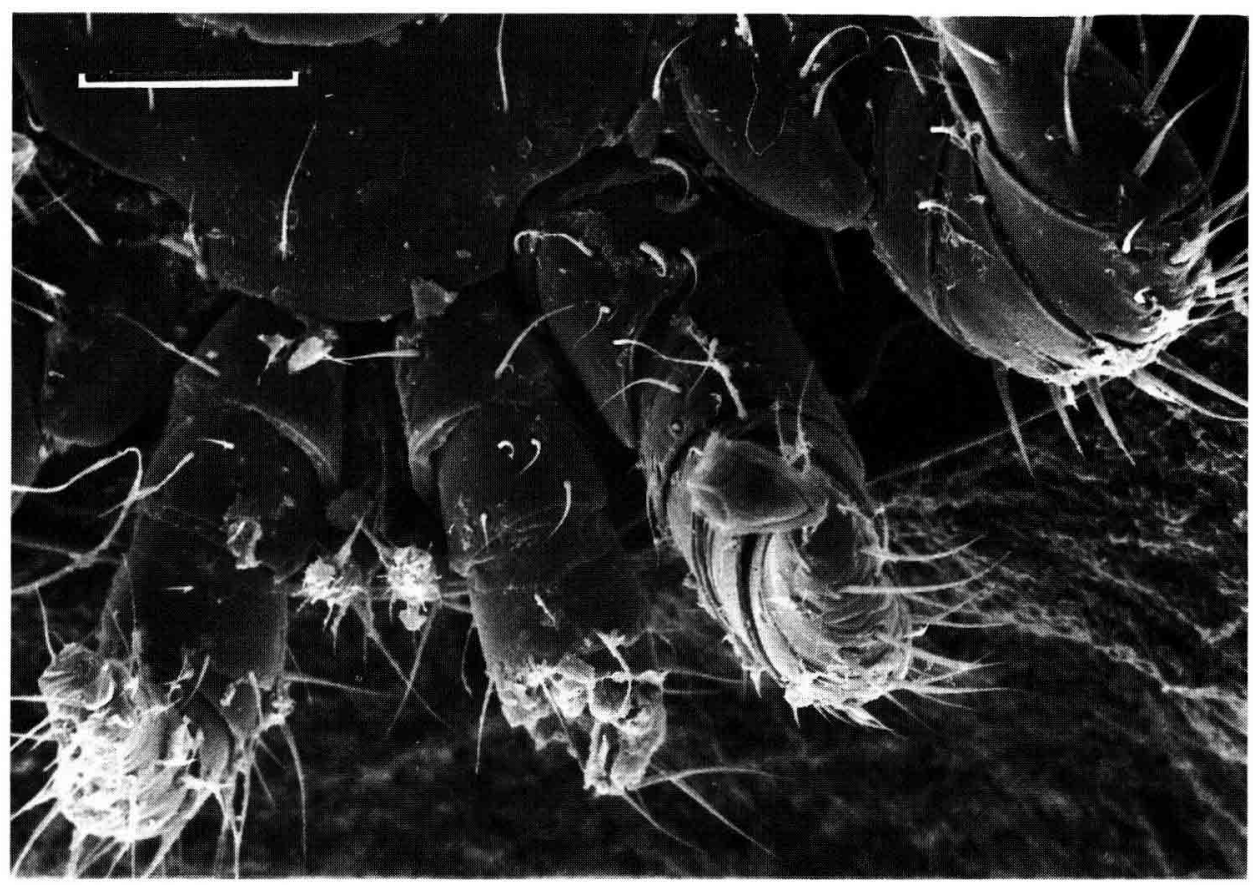

Fig 6. Damage at both front legs tips which appeared to be crushed rather than cut. hb: $0.1 \mathrm{~mm}$. 
Table II. Measurement of some body parts (in $\mathrm{mm}$ ) of $A \mathrm{~m}$ carnica (Austria) and $A c$ cerana (N China) (from Ruttner, 1988).

\begin{tabular}{lccccc}
\hline & $\begin{array}{c}\text { Tergite 3+4 } \\
\text { longitudinal }\end{array}$ & $\begin{array}{l}\text { Hind leg } \\
\text { length }\end{array}$ & $\begin{array}{c}\text { Hind wing } \\
\text { length }\end{array}$ & $\begin{array}{c}\text { Mandible } \\
\text { length }\end{array}$ & $\begin{array}{c}\text { Head } \\
\text { width }\end{array}$ \\
\hline A m carnica & 4.51 & 8.10 & 9.40 & 1.460 & 4.12 \\
A m cerana & 4.05 & 7.65 & 8.63 & 1.306 & 4.02 \\
\hline
\end{tabular}

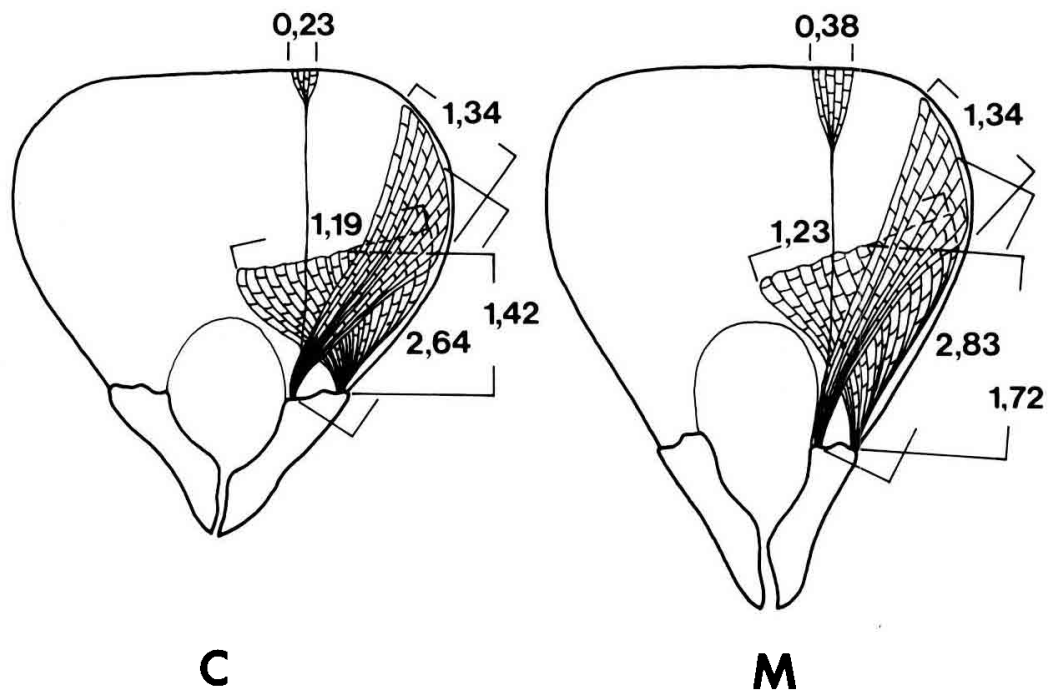

Fig 7. Head with mandibles and mandibular muscles of $A$ cerana cerana (C) and $A$ mellifera carnica (M). Measurements in $\mathrm{mm}$.

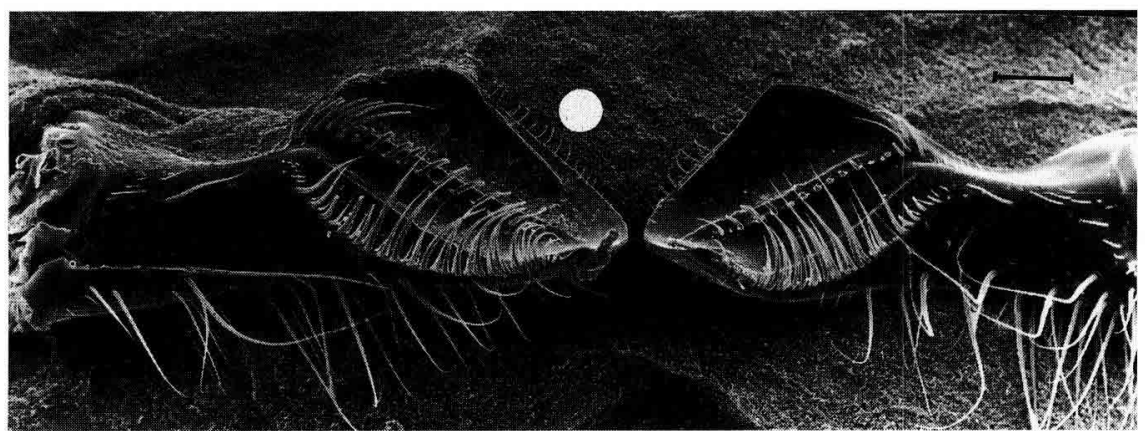

Fig 8. Mandibles showing the inner surface. Left: $A$ mellifera; right: $A$ cerana. White disc: mean diameter of Varroa hind leg. $\mathrm{hb}: 0.2 \mathrm{~mm}$. 


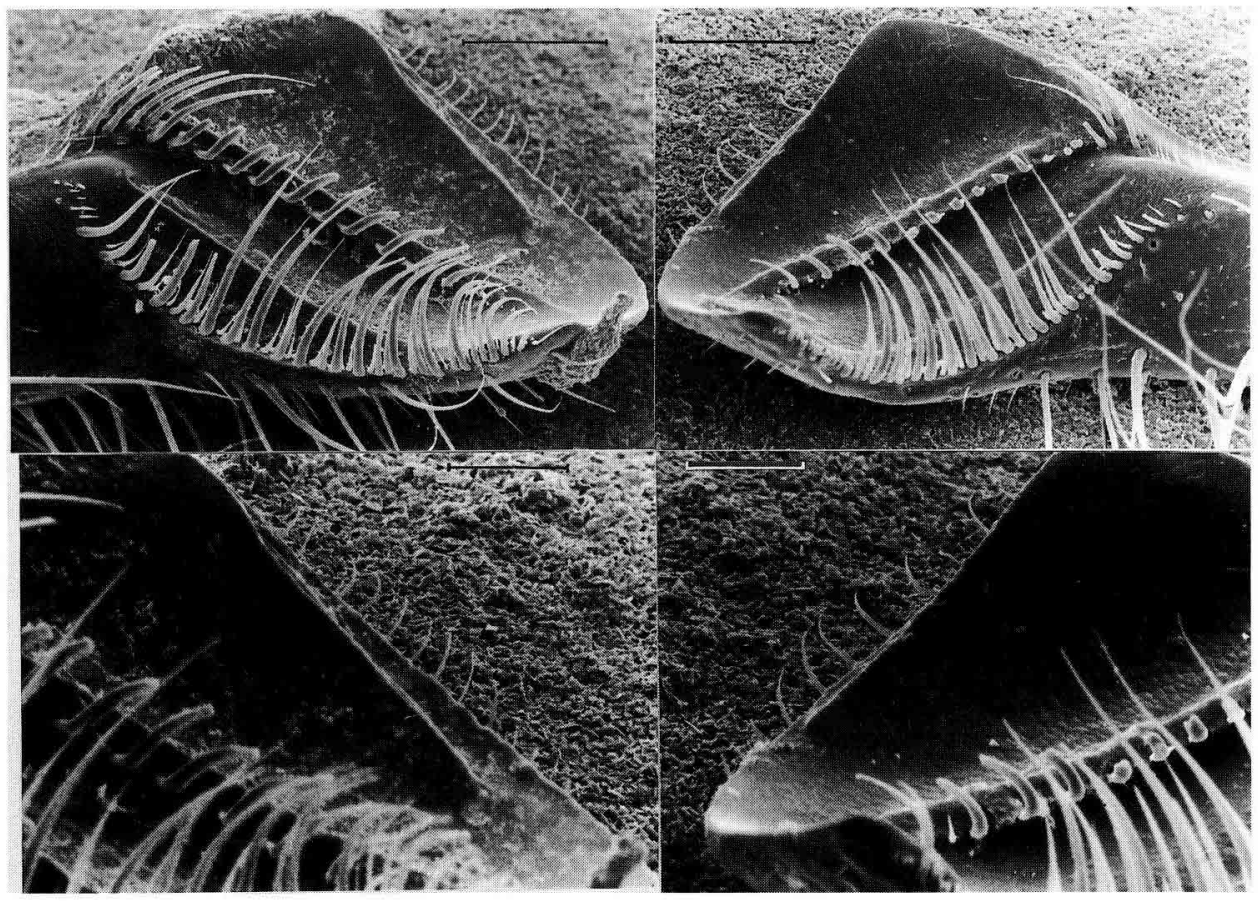

Fig 9. Mandibles shown at higher magnification. The second (inner) cutting edge of $A m$ (left) is only slightly developed in $A c$ (right). hb: $0.2 \mathrm{~mm}$ (top) and $0.1 \mathrm{~mm}$ (bottom).

\section{DISCUSSION}

Quoting an observation of Sakagami (1960), a defense reaction by means of damaging the Varroa mite is believed to be a rare event in $A$ mellifera because of its weak mandibular power. However, in the original text ( $p$ 183) this statement does not read as explicitly as it is frequently given: "When $C$ and $M$ are forced to a single duel, usually $M$ wins the victory because of its stronger muscular power. But the powerful mandibles of $C$ compensate to some extent her weakness" (see also Sakagami, 1959). Our present anatomical comparison of 2 northern subspecies of both species (figs 3,8 ) did not support this statement. The mandibles were found to be shorter in $A C$ cerana, and it can be questioned whether the muscular power is substantially greater in this species. The structure of the mandibular edge did not seem less suited for cutting in $A$ mellifera than in A cerana (figs 8-10).

The strongest argument for the capacity of $A$ mellifera workers to amputate the legs of Varroa mites was the evidence of freshly damaged mites. The mites were collected from the bottom board, still alive, only 10 minutes after they had been released from capped brood cells. The mutilated mites collected alive died within a few min- 


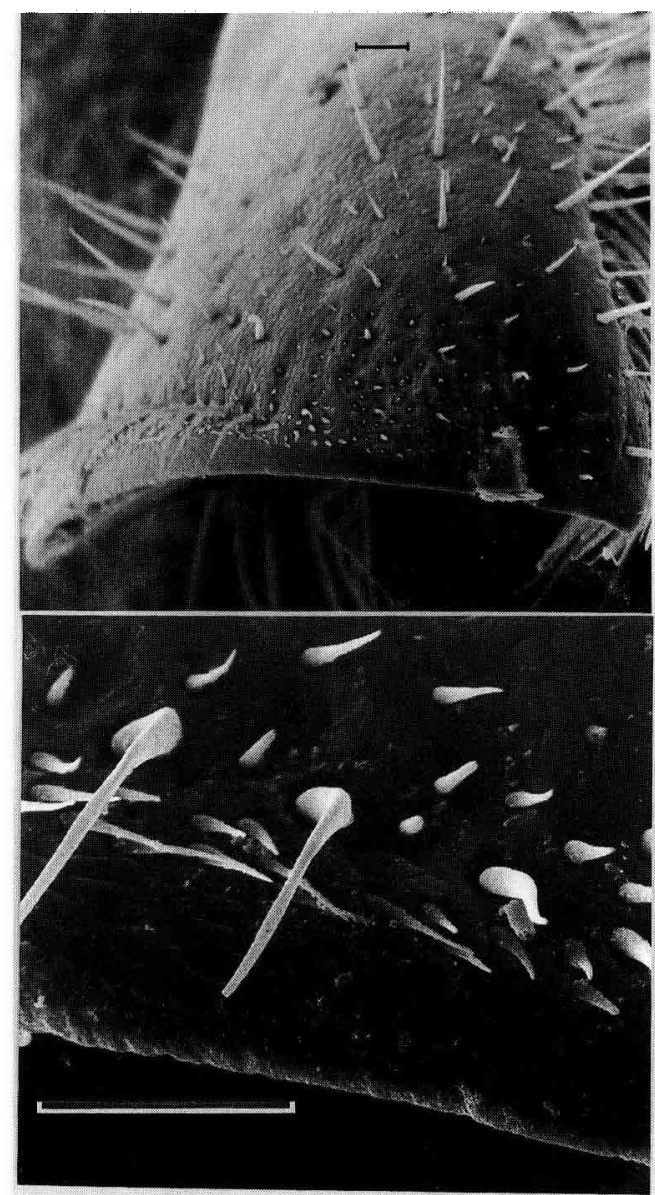

Fig 10. Mandibular cutting edge of $A$ mellifera, outer surface. Distal part of mandible (top), cutting edge at high magnification (bottom). hb: $0.05 \mathrm{~mm}$.

utes. Then the white tissue visible at the opening of the cut leg soon darkened and retracted inside the body giving an aspect similar to that in figure 1. Although the mites were not marked, their identity is undisputed because of their state of "gravidity" shown by the inflated idiosoma and the dehiscence of the ventral cuticular plates (in contrast to the flat phoretic individuals). Although not yet observed directly there seems to be no reasonable other explanation for the damaged mites than as the result of an aggressive behavior of the bees.

The inspection of the amputated legs gave a further clue. The surprisingly even, smooth section plane favors the idea of cooperation between the 2 edges of the mandibles like the 2 blades of a pair of scissors. The enlarged SEM photos of cut legs are remarkably similar to a neatly cut piece of ham (figs 3-5). The legs with their hard, chitinuous surface and the soft turgescent muscular content provide an ideal substratum for cutting even if the material is tough and hard to tear. The assumption of a scissor-like action is supported by the observation of an amputation clearly made by cuts effected at 2 different angles (fig 4), and the presence of tiny slices of muscular tissue by the additional mandibular edge (figs $3,8,9$ ). It should be kept in mind that the mandibles of Apoidea are very well suited for cutting, eg neatly cut cell cups of queens and drones, exactly cut pieces of rose leaves in Megachile. Considering the problem of the capacity of amputating mite legs, be it by $A$ cerana or by $A$ mellifera, the comparative size of mites and honey bees is to be kept in mind (fig 8): head width of $A$ mellifera worker bee (northern race) is about $4.1 \mathrm{~mm}$ compared to $1.2 \mathrm{~mm}$ of a female Varroa transversal body diameter. The length of the cutting edge of a worker's mandible (0.59 $\mathrm{mm}$ ) is more than 5 times the average diameter of a Varroa leg $(0.06-0.13 \mathrm{~mm})$. Considering this relatively huge tool, small differences in size are not likely to impair efficacy in dealing with a tiny object.

Although there was no major difference in the structure and functioning of the instruments of biting there certainly exists a difference in the frequency of the actual ef- 
fect. Amputated dead mites were found in many $A$ m carnica colonies, but only at a very low frequency. Higher frequencies $(25-50 \%)$ were found only in 12 out of 700 colonies. The complete behavioral repertory (self-grooming, grooming dance, nestmate grooming) as described by Peng et al (1987) in $A$ cerana was to be observed also in these colonies, but certainly at a lower frequency. In many cases a worker bee with a mite on top of the thorax was observed for quite a while without the bee in question or the nestmate paying any attention. The differences between $A$ cerana and $A$ mellifera as far as the parasitic mite Varroa is concerned are not found in their morphological and anatomical characteristics, but in their behavioral inventory. They are, however, only at a quantitative level, that also demonstrates the close relationship between the 2 species in this respect. It is to be expected that the active defense behavior against Varroa is frequently found in the European subspecies of $A$ mellifera to a varying degree. It seems to be especially highly developed in the "Africanized" bees of South America (Moretto et al, 1991).

The active defense reaction against Varroa mites has evidently nothing to do with general hygienic behavior, eg, nest cleaning. A cerana is definitely "disorderly" as far as removing rubbish from the hive bottom is concerned and therefore very susceptible to wax moths, but it is attentive towards Varroa; A mellifera carnica, on the other hand, always has a clean bottom board but it ignores the mites infesting the colony in most of its colonies. Therefore, these 2 characteristics should be clearly differentiated in the terminology.

The impact of this defense behavior on the population dynamics of Varroa is considerable. This is evidenced by our data from one colony. Colony No 13 had high mite infestation due to reinfection from neighboring colonies and also a high amputation rate (over $40 \%$ ). The mite mortality from September 1st to October 10th, 1991 , assessed by daily counts, amounted to a total of 1640 individuals. The remaining mite population in the colony, estimated from a sample of 304 bees, was about 1370 mites, that is $45.6 \%$ of the total $(=$ dead + remaining mites). Since mite removal continues during autumn and winter, although at a lower rate, while no new mites can be produced, this colony has a good chance of survival without help. As a high degree of heredity has been indicated by preliminary breeding assays, the character of active Varroa defense will probably play an important role in future programs of selecting a Varroa tolerant honeybee.

\section{ACKNOWLEDGMENTS}

We wish to thank M Keil (Hoechst AG) for taking the SEM pictures and A Mohr for the morphometric data, preparation of mandibles and for figure 3. C Rau and $E$ Hüttinger assisted with phototechnical skills and $\mathrm{C}$ Boigenzahn with statistical advice. H Pechhacker provided laboratory space and apicultural assistance. The main information, however, we owe to beekeeper Alois Wallner who was the first to observe the effects of the active Varroa defense behavior of $A m$ carnica honeybees and to select a strain with high manifestation of this characteristic.

Résumé - Défense active contre l'acarien Varroa jacobsoni chez une souche d'abeilles carnioliennes. Un apiculteur professionnel d'Autriche a sélectionné 12 colonies parmi ses 700 colonies d'abeilles carnioliennes (Apis mellifera carnica) pour le faible accroissement de leur population de varroas au cours de la saison apicole. Contrairement à toutes les autres colonies de la région qui avaient besoin de traite- 
ments acaricides réguliers pour survivre, ces colonies ont hiverné sans aucun traitement et se sont développées l'année suivante normalement en fournissant une récolte de miel correspondant à la moyenne. La mortalité des acariens dans les colonies sélectionnées, suivie journellement, à quelques exceptions près, du $1^{\text {er }}$ septembre 1990 au 30 avril 1991, était très élevée. Une partie des acariens morts était endommagée (pattes perdues, cuticule mutilée). Leur taux augmente parallèlement à la mortalité de façon significative. Les différences entre les colonies et entre les mois ne sont pas significatives en raison, vraisemblablement, du nombre restreint d'ob-servations.

Les acariens morts de 5 colonies ont été observés au microscope (tableau I). La mortalité moyenne par colonie durant la période expérimentale a été de 1235,8 acariens. Même réduite aux mois d'hiver (novembre-mars), la mortalité est 6 fois supérieure à celle trouvée par Moosbeckhofer (1991) chez des colonies non sélectionnées. La mortalité naturelle et l'infestation résiduelle ont été calculées pour une colonie : entre le $1^{\text {er }}$ septembre et le 10 octobre 1640 acariens ont été trouvés sur le plancher de la ruche; $40 \%$ étaient endommagés. À partir de l'examen d'un échantillon de 304 abeilles, on a estimé à environ 1370 le nombre d'acariens encore présents dans la colonie, soit $45,6 \%$ de l'effectif total (morts + survivants).

La lésion la plus fréquente est la perte totale ou partielle d'une ou de plusieurs pattes (fig 1), mais elle peut aller jusqu'à l'ablation totale de tous les organes ventraux (fig 2). Des mutilations de ce type sont connues comme faisant partie du comportement de défense d'A cerana, mais les mandibules d'A mellifera étaient considérées comme trop faibles pour agir ainsi. Des acariens fraîchement amputés mais encore vivants ont été obtenus en li- bérant 10-15 individus de cellules de couvain operculé de la même colonie sélectionnée. Dix minutes plus tard, on a retrouvé régulièrement un certain nombre d'acariens amputés remuant encore sur le plancher de la ruche. Les photos au MEB montrent clairement les faisceaux de muscles et la carapace chitineuse sectionnés par un instrument tranchant (figs 3-6). La seule cause plausible est le comportement de défense semblable à celui d'A cerana. L'anatomie comparée des mandibules et de leurs muscles (figs 7-10) ne fournit aucune preuve du manque de force des mandibules d'A mellifera. II faut supposer que la différence dans la défense active contre Varroa, qui existe entre $A$ cerana et $A$ mellifera et visiblement aussi entre les diverses races d'A mellifera, est due au fait que les ouvrières d'A mellifera ne reconnaissent pas Varroa comme un ennemi. Elles reconnaissent par contre très bien d'autres intrus, comme les larves de Galleria mellonella. On a pu montrer qu'en l'absence de traitement chimique, le comportement de défense active contre Varroa accroît les chances de survie des colonies d'A cerana sélectionnées. Cela fournit une base prometteuse pour sélectionner une abeille carniolienne plus résistante à Varroa.

\section{Apis mellifera carnica / résistance à Varroa / comportement de défense / am- putation / mandibule}

Zusammenfassung - Aktive VarroaAbwehr bei selektierten Völkern eines Carnica-Stammes. Ein Berufsimker in Österreich selektierte aus seinem Bestand von 700 Carnica-Völkern 12 Völker mit einem nur langsamen Anstieg der VarroaPopulation während der Saison. Im Gegensatz zu allen anderen Völkern der Region, die zum Überleben regelmäßiger medikamentöser Behandlung bedürfen, überwinterten diese Völker ohne jede $\mathrm{Be}$ - 
handlung und sie entwickelten sich in der folgenden Saison zu normaler Stärke mit einem dem Standmittel entsprechenden Ertrag. Der Milbenabfall der selektierten Völker, der vom 1 September bis zum 30 April mit wenigen Ausnahmen täglich protokolliert wurde, war sehr hoch. Die toten Milben zeigten teilweise Schäden verschiedenen Ausmaßes (Verlust von Beinen, Beschädigung des Chitinpanzers; Abb 1, 2). Der Anteil beschädigter Tiere stieg mit der Milbenmortalität signifikant an. Die Unterschiede zwischen den Völkern und Monaten waren statistisch nicht signifikant, wahrscheinlich wegen zu geringer Zahl von Beobachtungen.

Die toten Milben aus fünf Völkern wurden unter dem Mikroskop untersucht (Tabelle I). Der mittlere natürliche Milbenabfall je Volk betrug in der Untersuchungsperiode 1235,8 Tiere. Selbst wenn man den Abfall nur für die eigentlichen Wintermonate (November - März) heranzieht, so entspricht die Zahl dem Sechsfachen dessen, was Moosbeckhofer (1991) bei unselektionierten Völkern festgestellt hatte. Bei einem Volk wurden natürlicher Abfall und Restbefall bestimmt: zwischen 1,9 und 10,10 wurden insgesamt 1640 Milben auf dem Bodenbrett gefunden, $40 \%$ von ihnen beschädigt; aus der Hochrechnung des Befalls von 304 untersuchten Bienen wurde geschätzt, daß im Volk nur etwa 1340 Milben verblieben waren, das sind $45,6 \%$ der ursprünglichen Gesamtzahl.

Als häufigste Beschädigung der Milben wurde der Verlust eines oder mehrerer Beine, ganz oder teilweise, festgestellt (Abb 1), bis zur beinahe vollständigen Entfernung sämtlicher ventraler Organe (Abb 2). Verletzungen dieser Art sind als Teil des Verteidigungsverhaltens von Apis cerana bekannt, aber bei $A$ mellifera wurden die Mandibeln für derartige Effekte für zu schwach gehalten.
Frisch amputierte, noch lebende Milben wurden durch Freisetzung von 10-15 Individuen aus frisch verdeckelten Brutzellen desselben, selektierten Volkes gewonnen. Regelmäßig wurde etwa 10 min später eine Anzahl amputierter, noch bewegungsfähiger Milben am Bodenbrett gefunden. Rasterelektronenmikroskopische Aufnahmen zeigen sehr deutlich frische Muskelbündel und das Chitin der Körperdecke, alles glatt durchgeschnitten von einem offensichtlich scharfen Instrument (Abb 3-6). Die einzige plausible Erklärung für diesen Effekt ist dieselbe aktive Varroaverteidigung durch Arbeitsbienen, wie sie bei $A$ cerana beobachtet wurde. Ein anatomischer Vergleich der Mandibeln und ihrer Muskeln (Abb 7-10) ergab kein Argument für eine wesentlich geringere Mandibelkraft bei $A$ mellifera.

Es ist anzunehmen, daß die Unterschiede in der aktiven Varroaabwehr, die zwischen $A$ cerana und $A$ mellifera und offensichtlich auch zwischen verschiedenen Rassen von $A$ mellifera bestehen, auf einem Mangel der Fähigkeit der Bienen dieser Art beruhen, die Varroa-Milbe als Feind zu erkennen. Andererseits erkennen sie aber andere Feinde, wie zB Wachsmottenlarven, sehr gut als solche. Es konnte gezeigt werden, daß die aktive Varroaabwehr die Chance von selektierten Carnica-Völkern erhöht, auch ohne chemische Behandlung zu überleben. Das ergibt eine vielversprechende Grundlage zur Auslese einer besser varroatoleranten Carnica-Biene.

Apis mellifera carnica / Varroa Resistenz / Verteidigungsverhalten / Amputation / Mandibel

\section{REFERENCES}

Moosbeckhofer R (1991) Varroaverluste während der Überwinterung. Bienenvater 112, 300-303 
Moretto G, Gonçalves LS, De Jong D (1991) Africanized bees are more efficient at removing Varroa jacobsoni - preliminary report. Am Bee J 131(7) 434

Peng YS, Fang $Y, X u S, G e L$ (1987) The resistance mechanism of the Asian honeybee, Apis cerana Fabr, to an ectoparasitic mite Varroa jacobsoni Oud. J Invertebr Pathol 40, 54-60

Ruttner F (1988) Biogeography and Taxonomy of Honeybees. Springer, Heidelberg

Ruttner $F$ (1991) Auf dem Wege zu einer varroatoleranten Carnica. Allg Dtsch Imkeztg 25 (11) $10-15$
Ruttner F, Marx H, Marx G (1984) Beobachtungen über eine mögliche Anpassung von Varroa jacobsoni an Apis mellifera in Uruguay. Apidologie 15, 43-62

Sakagami SF (1959) Some interspecific relations between Japanese and European honeybees. J Anim Ecol 28, 51-68

Sakagami SF (1960) Preliminary report on the specific difference of behaviour and other ecological characters between European and Japanese honeybees. Acta Hymenopterol 1, 171-198

Wallner A (1990) Imkern heute. Selbstverlag A-263 Randegg, Austria 